\title{
Development and Initial Validation of Stigma Towards Healthcare Providers Working with COVID-19 Patients Scale (SI9-HCPs)
}

\author{
Abdulqadir J Nashwan ${ }^{1,2}$ \\ Sadeq Al-Fayyadh (iD ${ }^{3}$ \\ Hayder AL-Hadrawi ${ }^{4}$ \\ Mohammed Baqer Al-jubouri ${ }^{3}$ \\ Sabah A Jaafar (iD ${ }^{5}$ \\ Shaymaa $M$ Hussein $^{3}$ \\ Ayat J Nashwan ${ }^{6}$ \\ Mohammed A Alharahsheh ${ }^{6}$ \\ Nisha Kader (iD ${ }^{7}$ \\ Majid Alabdulla ${ }^{7,8}$ \\ 'Department of Nursing Education \& \\ Practice Development, Hazm Mebaireek \\ General Hospital (HMGH), Hamad \\ Medical Corporation (HMC), Doha, \\ Qatar; ${ }^{2}$ Faculty of Nursing, University of \\ Calgary in Qatar (UCQ), Doha, Qatar; \\ ${ }^{3}$ College of Nursing, University of \\ Baghdad, Baghdad, Iraq; ${ }^{4}$ College of \\ Nursing, University of Kufa, Kufa, Iraq; \\ ${ }^{5}$ College of Nursing, University of \\ Muthanna, Baghdad, Iraq; ${ }^{6}$ Department of \\ Sociology and Social Work, Yarmouk \\ University, Irbid, Jordan; ${ }^{7}$ Mental Health \\ Services (MHS), Hamad Medical \\ Corporation (HMC), Doha, Qatar; \\ ${ }^{8}$ College of Medicine, Qatar University, \\ Doha, Qatar
}

Correspondence: Abdulqadir J Nashwan Department of Nursing Education \& Practice Development, Hazm Mebaireek General Hospital (HMGH), Hamad Medical Corporation (HMC), P.O.Box 3050, Doha, Qatar

Tel +974 40240487; +97466473549

Email anashwan@hamad.qa
Purpose: The S19-HCPs tool evaluates the stigma towards healthcare providers working with patients with COVID-19.

Materials and Methods: The psychometric properties of the Arabic and English versions of the S19-HCPs were examined. A survey using the S19-HCPs scale was administered online. Two reliability analyses were used in this study to identify the extent to which S19HCPs shows consistent results (internal consistency and test-retest reliability). The English version of the scale was piloted on 33 Jordanian and the Arabic version on 27 Iraqi participants.

Results: The internal consistency of the English and Arabic S19-HCPs was satisfactory $(\alpha=$ $0.79,0.74$, respectively). Two-week test-retest correlations were all statistically significant (ICC $=0.91,0.89$, respectively).

Conclusion: The S19-HCPs is psychometrically robust and can be used in research assessing the stigma towards healthcare providers working with patients with COVID-19 in English and Arabic-speaking countries.

Keywords: coronavirus, COVID-19, stigma, S19-HCPs, Arabic S19-HCPs, English S19HCPs

\section{Introduction}

Since December 2019, severe acute respiratory syndrome coronavirus-2 (SARSCoV-2), the novel coronavirus first detected in China (Wuhan, Hubei Province), which caused coronavirus disease 2019 (COVID-19), many developed and developing health care systems are facing unprecedented circumstances. Examples of such challenges are, however, not limited to social, economic, and, most importantly, healthcare-related challenges. ${ }^{1,2}$ The literature has focused on highlighting the catastrophic burdens of such a pandemic on the general population regarding its high morbidity and mortality rates. Ten months after the first confirmed case of COVID-19, there are approximately 37 million confirmed cases of COVID-19, including more than one million deaths, as globally reported by the World Health Organization. $^{3}$

Despite the imposed partial or full quarantine, awareness-raising campaigns focusing on social distancing, and strict infection control policies, such alarming statistics are still growing on a daily basis. Nurses, physicians, and clinical pharmacists are the front-line health care providers who are sacrificing their lives to help their patients facing this fierce pandemic. Unless supporting the frontline health 
care providers physically, socially, financially, and psychologically, the global war against the pandemic might end up with huge consequences. ${ }^{4}$ Among the many challenges facing the frontline health care providers during the pandemic, the psychosocial burdens, which are represented by COVID-19-related stigma, are the most prominent and, at the same time, overlooked danger. ${ }^{5}$ Stigma is defined as "any social or physical trait or gesture that disqualifies an individual's social identity, such as disqualifying them from full social acceptance". 6

Stigmatization is especially common in disease outbreaks and pandemic situations. As confirmed in psychology, persons are usually afraid of the unknown. ${ }^{7}$ In contrast, COVID-19 is a new disease, and for which there are still many unknowns, social stigma against health care providers who are taking care of COVID-19 patients is highly expected. ${ }^{7}$ Stigma is prevalent and well researched concerning mental illness, non-communicable (eg, cancers), and communicable diseases (human immunodeficiency virus (HIV), Ebola virus disease (EVD), and tuberculosis (TB)). ${ }^{8}$

Stigma has many drivers leading to stigmatization including the fear of infection, blame, stereotypes, social judgment, lack of awareness, fear of social ramifications, and prejudice, ${ }^{9}$ mainly fueled by the pandemic of misinformation and linked to certain racial and ethnic groups, eg, "Wuhan" or "Chinese" virus. However, inadequate and inconclusive research on COVID-19 transmission and preventive measures as well as the chaos of sharing COVID-19 news and updates raises apprehension among the public, leading to mistrust in healthcare services. ${ }^{9}$

However, studies about the stigma against health care providers who are taking care of patients with COVID-19 are minimal. According to the World Health organization (WHO), ${ }^{10}$ the frontline healthcare providers are challenged by stigma, social isolation, and discrimination in the workplace environment and their social surroundings during the pandemic time. Victimization of the front-line health care providers taking care of COVID-19 patients by stigma may negatively impact their focus and decrease the efficiency of making sound decisions. ${ }^{11}$ The impact of such circumstances cannot be limited to the psychological wellbeing of health care providers. Still, it can also affect their professional competencies to provide quality care to the population during the pandemic time..$^{11,12}$

Therefore, this research endeavor was principally designed for examining the psychometric properties of both English and Arabic versions of S19-HCPs, which was newly developed by the authors of this study. Fulfilling such an endeavor would contribute to filling the existed gap in the literature. Of equal importance, it would provide both reliable and valid tools by which the stigma associated with COVID-19 can be assessed in healthcare settings around the world, equipping interested researchers with both a reliable and valid tool as a sound foundation of stigma interventions and related education.

\section{Materials and Methods Development of the Scale}

The development of the S19-HCPs instrument has been guided by McCoach et $\mathrm{al}^{13}$ methodology. First, a thorough literature review was conducted to assess all tools measuring stigma. Several measures on stigma were identified in different populations and diseases such as HIV and Tuberculosis. All relevant items were compiled by two researchers (AJN and NKA). Thirty-one items were retained for further evaluation after eliminating duplicate content and expressions.

Second, the 31 items were evaluated by an expert panel (including two senior mental health consultants, a sociologist, general physician, pharmacist, and nurse); additional 4 items were eliminated based on the expert panel's suggestions.

Third, the remaining 27 items were sent out to be furtherly reviewed by a second expert panel (including healthcare providers). Three items were further omitted based on their comments. The participants indicated no changes were needed; thus, no further changes were made. Thus, the total number of retained items were 24 .

\section{Participants and Procedure}

The healthcare providers practicing in healthcare facilities in Iraq and Jordan were considered the target population (English is the official teaching language in all Jordanian universities). Inclusion criteria were being a healthcare provider (physician, nurse, clinical pharmacist) and understanding spoken Arabic or English. Participants were invited to complete an anonymous, voluntarily online survey $\left(\mathrm{QSurvey}{ }^{\mathrm{TM}}\right.$ ), and the link has been shared through emails and social media platforms using a snowball sampling strategy. The English version of the scale was piloted on 33 Jordanian and the Arabic version on 27 Iraqi participants.

\section{Ethical Considerations}

The Ethics Committee approved all study activities of both University of Baghdad (UoB) in Iraq (Ref 20-09-2020) 
and Jordan University of Science and Technology (JUST) in Jordan (Ref 15-10-2020). All participants provided informed consent, and that this study was conducted in accordance with the Declaration of Helsinki.

\section{Translation of S19-HCPs into Arabic}

The Forward-backward translation technique was utilized to translate the original S19-HCPs into Arabic. ${ }^{14}$ Initially, the S19-HCPs was translated into Arabic by the first author (AJN), who is fluent in English and Arabic. Then, the provisional Arabic translation has been reviewed by a co-author (SA)(bilingual) for any anomalies and inconsistencies. Lastly, the back-translation into English was done by another co-author (AJJN), who was unfamiliar with the original English version. Both translations were checked for cultural appropriateness and compared for equivalence by all authors for any further modifications. The final English and Arabic versions of the S-19-HCPs can be found in Appendix A.

\section{Demographic Information}

Seven questions were added to ask about the demographic data of the participants, including country of residence and work, age group, gender, occupation, working in COVID19 designated facilities, and whether they have received any educational activities related to stigma.

\section{Data Analysis}

Descriptive statistics were used to describe participants' characteristics. Psychometric properties were measured utilizing internal consistency and test-retest reliability to identify the extent to which the S-19-HCPs scale shows consistent results. Reliability analyses are crucial for newly developed scale to identify the stability and dependability of the items or the subscale parts in terms of measuring the construct that the scale is designed to measure $^{15,16}$ and the acceptable reliability value is 0.70 or higher. ${ }^{16,17}$

\section{Internal Consistency Reliability}

This reliability analysis was used to measure the level of consistency among various items on the S-19-HCPs scale. It works by correlating each item in the construct with the rest of the items on the same construct to identify the coefficient value by which the internal consistency is determined.

\section{Test-Retest Reliability}

The S19-HCPs scale consists of 27 items that are rated and scored differently. Eight items are rated on a three-point Likert scale, and 19 items are rated on a four-point Likert scale, which could affect the inter-item correlation. Therefore, test-retest reliability analysis can show a more accurate reliability ratio. According to Anastasi and Urbina, ${ }^{18}$ the cumulative effect of individual, social, and environmental factors can progressively reduce the correlation between test and retest results; therefore, 2 weeks was estimated between the first assessment (test) and the second assessment (retest) on the same sample to reduce the effect of the aforementioned factors on the retest correlation. Also, each item was assessed for its impact on the overall alpha correlation coefficient. PSS Statistics Software (v.25) and Microsoft Excel Packages were used to analyze the collected data.

\section{Results}

\section{English Version}

The English version of the scale was piloted on $(n=33)$ from Jordan mostly 20-30 age group, and more than half the participants were nurses $(\mathrm{n}=18 ; 55 \%)$ and females $(\mathrm{n}$ $=19 ; 58 \%$ ), and more than half of the participants were working in COVID-19 designated facilities $(n=20 ; 60 \%)$, the vast majority did not receive any training related to stigma in general or even the one associated with COVID$19(\mathrm{n}=31 ; 94 \%)$ (see Table 1). The internal consistency of the S19-HCPs' English version was satisfactory $(\alpha=0.79)$ (see Table 2). Two-week test-retest correlations were all statistically significant (ICC $=0.91, p=0.01)$ (see Table 3 ).

\section{Arabic Version}

The Arabic version of the scale was piloted on $(n=27)$ from Iraq mostly 20-30 age group, and more than the participants were nurses $(n=25 ; 93 \%)$ and females $(n=$ $15 ; 56 \%$ ), and more than half of the participants were working in COVID-19 designated facilities $(n=19$; $70 \%$ ), the vast majority did not receive any training related to stigma in general or even the one associated with COVID-19 ( $\mathrm{n}=23 ; 85 \%)$ (see Table 1). The internal consistency of the Arabic version ofS19-HCPs was satisfactory $(\alpha=0.74)$ (Table 2$)$. Two-week test-retest correlations were all statistically significant $(\mathrm{ICC}=0.89$, $p=0.01$ ) (see Table 3).

Confirmatory factor analysis was run to measure the validity of the constructed Arabic version of the 
Table I Participants' Characteristics

\begin{tabular}{|l|c|c|c|c|}
\hline & \multicolumn{2}{|c|}{$\begin{array}{c}\text { English } \\
\text { Version } \\
\text { (n=33) }\end{array}$} & \multicolumn{2}{c|}{$\begin{array}{c}\text { Arabic } \\
\text { (n=27) }\end{array}$} \\
\cline { 2 - 5 } & Freq & (\%) & Freq & (\%) \\
\hline Gender & & & & \\
Male & 14 & 42.4 & 12 & 44.4 \\
Female & 19 & 57.6 & 15 & 55.6 \\
\hline Age group (years) & & & & \\
20-30 & 23 & 69.7 & 19 & 70.4 \\
$31-40$ & 5 & 15.2 & 4 & 14.8 \\
$41-50$ & 3 & 9.1 & 4 & 14.8 \\
5I+ & 2 & 6.1 & 0 & 0.0 \\
\hline Occupation & & & & \\
Physician & 9 & 27.3 & 0 & 0.0 \\
Nurse & 18 & 54.5 & 25 & 92.6 \\
Others & 6 & 18.2 & 2 & 7.4 \\
\hline Experience in healthcare (years) & & & & \\
I-5 & 20 & 60.6 & 17 & 63.0 \\
6-10 & 8 & 24.2 & 3 & 11.1 \\
II-20 & 3 & 9.1 & 5 & 18.5 \\
$21+$ & 2 & 6.1 & 2 & 7.4 \\
\hline
\end{tabular}

COVID-19 related stigma scale. The total variance table shows that out of 27 factors, there were nine factors with eigenvalues greater than 1 . Six factors were identified (see Table 4) and primarily named as anxiety or fear of being affected, practices to avoid being infected by COVID-19, attitudes about the affected individuals, being avoided or judged by others, health care settings' policies and procedures, and willingness to care for COVID-19 patients. Varimax rotation was also used to clarify the variance shared by the scale items and explain the loading of factors. Rotated Component Matrix (see Table 5) clarifies which factor is represented by which items; items that are loaded on the same factor are correlated with each other's. Eight items appear to share variance with items across factors.

1. Anxiety of being affected is represented by seven items $(1,2,3,4,5,6$, and 15).

2. Practices to avoid being infected by COVID-19 is represented by six items $(8,9,21,22,23$, and 25$)$.

3. Attitudes about the affected individuals is represented by six items $(15,16,17,18,24$, and 27$)$.

4. Being avoided or judged by others is represented by four items (13, 14, 15, and 26).
5. Health care settings' policies is represented by six items $(3,4,9,10,12$, and 14).

6. Willingness to care for COVID-19 patients is represented by six items $(1,11,19,20,25$, and 27$)$.

\section{Discussion}

The majority of reviewed studies suggested that stigmatization insinuates important health and mental implications on individuals affected by infectious diseases. More specifically, the stigma associated with the most common viral infections such as human immunodeficiency virus (HIV), hepatitis C virus (HCV), tuberculosis, Zika, and the recent COVID-19 is present in all parts of society including educated and urban individuals. ${ }^{19}$ However, stigma predominantly influenced countries with trickling effects of the global economic crisis in the past decade, particularly affecting access to healthcare. ${ }^{20}$ For this reason, this study focused on countries affected by the global economic crisis such as Jordan and Iraq.

Furthermore, Van Rie et al developed scales to measure tuberculosis (TB) and HIV/AIDS stigma in a global context. The internal consistency was satisfactory (Cronbach's alphas $0.82-0.91$ ), test-retest reliability was moderate, and construct validity showed an inverse correlation with social support. ${ }^{21}$ The results proved good psychometric properties that measure stigma associated with $\mathrm{TB}$ and HIV/AIDS from community and patient perspectives. Research on stigma is very helpful in assessing the burden of stigma, guiding the development of effective interventions, and evaluating stigma reduction programs in areas with disease outbreaks.

Similarly, Drewes and Kleiber (2014) conducted an experimental study where 752 participants were included. The researchers assessed the effect of the reduction in HIV contagiousness on stigmatization. Participants were asked to rate their willingness to stigmatize an individual by responding to two measures of social and physical distancing. Participants rated an individual only after reading a short vignette describing an HIV-positive patient diagnosed with either a high or low viral load of HIV. Additionally, the participants were split in half: those who were informed on the association between viral load and contagiousness and those who were not informed. ${ }^{22}$ The results further suggest the relationship between infectious disease and stigmatization; only this time, the stigma was associated with the level of contagiousness. Moreover, 
Table 2 Internal Consistency Reliability of the S19-HCPs Tool

\begin{tabular}{|c|c|c|}
\hline \multirow[t]{2}{*}{ Items } & $\begin{array}{l}\text { English } \\
\text { Version }\end{array}$ & $\begin{array}{l}\text { Arabic } \\
\text { Version }\end{array}$ \\
\hline & \multicolumn{2}{|c|}{ Cronbach's Alpha } \\
\hline Item I: Are you worried about getting infected with COVID-I9? & 0.74 & 0.736 \\
\hline Item 2: How worried would you be about getting COVID-I9 if you touched the clothing of a patient with COVID-I9 & 0.74 & 0.737 \\
\hline $\begin{array}{l}\text { Item 3: How worried would you be about getting COVID-I9 if you dressed the wounds of a patient with } \\
\text { COVID-19 }\end{array}$ & 0.75 & 0.704 \\
\hline Item 4: How worried would you be about getting COVID-I9 if you drew blood from a patient with COVID-I9 & 0.86 & 0.718 \\
\hline $\begin{array}{l}\text { Item 5: How worried would you be about getting COVID-19 if you took the temperature of a patient with } \\
\text { COVID-19 }\end{array}$ & 0.71 & $0.7 I I$ \\
\hline Item 6: How worried would you be about getting COVID-19 if you examine (physically) a patient with COVID-19 & 0.85 & 0.704 \\
\hline $\begin{array}{l}\text { Item 7: Do you typically use any of the following measures when providing care or services for a patient with } \\
\text { COVID-19? Avoid physical contact }\end{array}$ & 0.73 & 0.725 \\
\hline $\begin{array}{l}\text { Item 8: Do you typically use any of the following measures when providing care or services for a patient with } \\
\text { COVID-19? Wear a double mask or N95 mask only }\end{array}$ & 0.86 & 0.726 \\
\hline $\begin{array}{l}\text { Item 9: Do you typically use any of the following measures when providing care or services for a patient with } \\
\text { COVID-19? Wear double gloves }\end{array}$ & 0.73 & 0.726 \\
\hline $\begin{array}{l}\text { Item 10: Do you typically use any of the following measures when providing care or services for a patient with } \\
\text { COVID-19? Wear gloves during all aspects of the patient's care }\end{array}$ & 0.82 & 0.722 \\
\hline $\begin{array}{l}\text { Item II: Do you typically use any of the following measures when providing care or services for a patient with } \\
\text { COVID-19? Use any special infection-control measures with patients with COVID-19 that you do not use with } \\
\text { other patients }\end{array}$ & 0.86 & 0.720 \\
\hline Item I2: Healthcare workers unwilling to care for a patient with or thought to have COVID-I9. & 0.84 & 0.742 \\
\hline $\begin{array}{l}\text { Item 13: If you have the choice; Do you prefer to work with other types of patients rather than COVID-I9 } \\
\text { patients? }\end{array}$ & 0.74 & 0.738 \\
\hline $\begin{array}{l}\text { Item I4: In the past } 12 \text { months, how often have you observed the following in your health facility? Healthcare } \\
\text { workers providing poorer quality of care to a patient with or thought have COVID-19. }\end{array}$ & 0.88 & 0.733 \\
\hline $\begin{array}{l}\text { Item I5: In the past } 12 \text { months, how often have you observed the following in your health facility? Healthcare } \\
\text { workers talking badly about people with or thought to have COVID-19. }\end{array}$ & 0.72 & 0.698 \\
\hline $\begin{array}{l}\text { Item 16: In the past } 12 \text { months, how often have you experienced the following? Experienced people were talking } \\
\text { badly about you because you care for patients with COVID-19. }\end{array}$ & 0.74 & 0.740 \\
\hline $\begin{array}{l}\text { Item I7: In the past } 12 \text { months, how often have you experienced the following? Been avoided by friends and family } \\
\text { because you care for patients with COVID-19. }\end{array}$ & 0.79 & 0.714 \\
\hline $\begin{array}{l}\text { Item I8: In the past } 12 \text { months, how often have you experienced the following? Been avoided by colleagues because } \\
\text { of your work caring for patients with COVID-19. }\end{array}$ & 0.76 & 0.713 \\
\hline $\begin{array}{l}\text { Item 19: How hesitant are healthcare workers in this facility to work alongside a co-worker who got recovered } \\
\text { from COVID-19? }\end{array}$ & 0.75 & 0.746 \\
\hline Item 20: Do you think you will get into trouble at work if you discriminate against patients with COVID-I9. & 0.82 & 0.754 \\
\hline Item 2I: There are adequate supplies in my health facility that reduce my risk of becoming infected with COVID-I9. & 0.73 & 0.732 \\
\hline
\end{tabular}

(Continued) 
Table 2 (Continued).

\begin{tabular}{|l|c|c|}
\hline Items & $\begin{array}{c}\text { English } \\
\text { Version }\end{array}$ & \multicolumn{1}{c|}{$\begin{array}{c}\text { Arabic } \\
\text { Version }\end{array}$} \\
\cline { 2 - 3 } & \multicolumn{2}{c|}{ Cronbach's Alpha } \\
\hline $\begin{array}{l}\text { Item 22: There are standardized procedures/protocols in my health facility that reduce my risk of becoming } \\
\text { infected with COVID-19 }\end{array}$ & 0.74 & 0.74 I \\
\hline Item 23: My health facility has written guidelines to protect patients with COVID-19 from discrimination. & 0.83 & 0.73 I \\
\hline Item 24: Most people with COVID-19 do not care if they infect other people. & 0.86 & 0.733 \\
\hline Item 25: People with COVID-19 should feel ashamed of themselves. & 0.76 & 0.763 \\
\hline Item 26: Getting infected with COVID-19 is a person's own fault. & 0.78 & 0.766 \\
\hline Item 27: People get infected with COVID-19 because they engage in irresponsible behaviors. & 0.87 & 0.743 \\
\hline Overall Cronbach's alpha & 0.786 & 0.739 \\
\hline
\end{tabular}

Table 3 Test-Retest Reliability

\begin{tabular}{|c|c|c|c|c|}
\hline \multirow[b]{2}{*}{$\begin{array}{l}\text { Descriptive } \\
\text { Statistics }\end{array}$} & \multicolumn{2}{|c|}{$\begin{array}{c}\text { English Version } \\
\quad(n=33)\end{array}$} & \multicolumn{2}{|c|}{$\begin{array}{c}\text { Arabic Version } \\
(n=27)\end{array}$} \\
\hline & Mean & $\begin{array}{l}\text { Std. } \\
\text { Deviation }\end{array}$ & Mean & $\begin{array}{l}\text { Std. } \\
\text { Deviation }\end{array}$ \\
\hline Test I & 2.55 & 0.59 & 2.49 & 0.47 \\
\hline Retest & 2.56 & 0.63 & 2.47 & 0.52 \\
\hline $\begin{array}{l}\text { Pearson } \\
\text { Correlation }\end{array}$ & \multicolumn{2}{|r|}{$0.91 *$} & \multicolumn{2}{|r|}{$0.89 *$} \\
\hline
\end{tabular}

Note: *Correlation is significant at the 0.01 level (2-tailed).

the results also illustrate the stigma targeting healthcare workers; those uninformed on the association between viral load and contagiousness could perceive healthcare workers as more contagious since they are constantly on the frontlines of global pandemics.

While all the previous studies focused on the stigma towards the people affected by various infectious diseases, very few studies brought attention to the physical and mental implications of stigma targeting health care workers who are in the frontline. In one recent study, Abdelhafiz and Alorabi (2020) recommended that providing emotional support during different stages can help HCPs overcome the actual or potential psychological impact of stigma. Additionally, providing healthcare workers with emotional support highlights a positive and important influence at the national level. ${ }^{23}$ Psychological support should be available and provided by well-trained professionals to all affected individuals and groups, including healthcare workers not only for their value as human beings but for their essential contribution to society. Another recent study by Tomlin et al assessed the psychological impact of COVID-19 on healthcare workers. The pandemic leads to short and long-term mental health problems such as high rates of psychological stress, depression, anxiety, and insomnia. ${ }^{24}$ However, a model such as the one suggested by Tomlin et al could be integrated into health facilities as a guideline to help healthcare workers fight mental stressors. Their phased model considers personal and workrelated healthcare worker mental burdens, as well as, an evaluation of the outcomes of the interventions highlighted by the phased model. The outcome evaluation gives health facilities and administrations the opportunity to adjust this phased model based on the needs of the hospital and the intensity of the mental burdens on their staff. By addressing contextual burdens such as financial, familial, and other personal commitments, the health facility can work with the healthcare workers to alleviate some of their stress.

In the US, violence against Asian Americans (including healthcare providers) has persisted at high rates throughout the COVID-19 pandemic and even during the SARS outbreak. Asian and Black Americans more likely than other groups to report negative experiences because of their race or ethnicity since the COVID-19 outbreak. ${ }^{27}$

A recent cross-sectional study has revealed that a considerable proportion of Egyptian physicians experienced COVID-19-related stigmatization. ${ }^{28}$ In Ghana, a study recommends that the COVID-19 National 


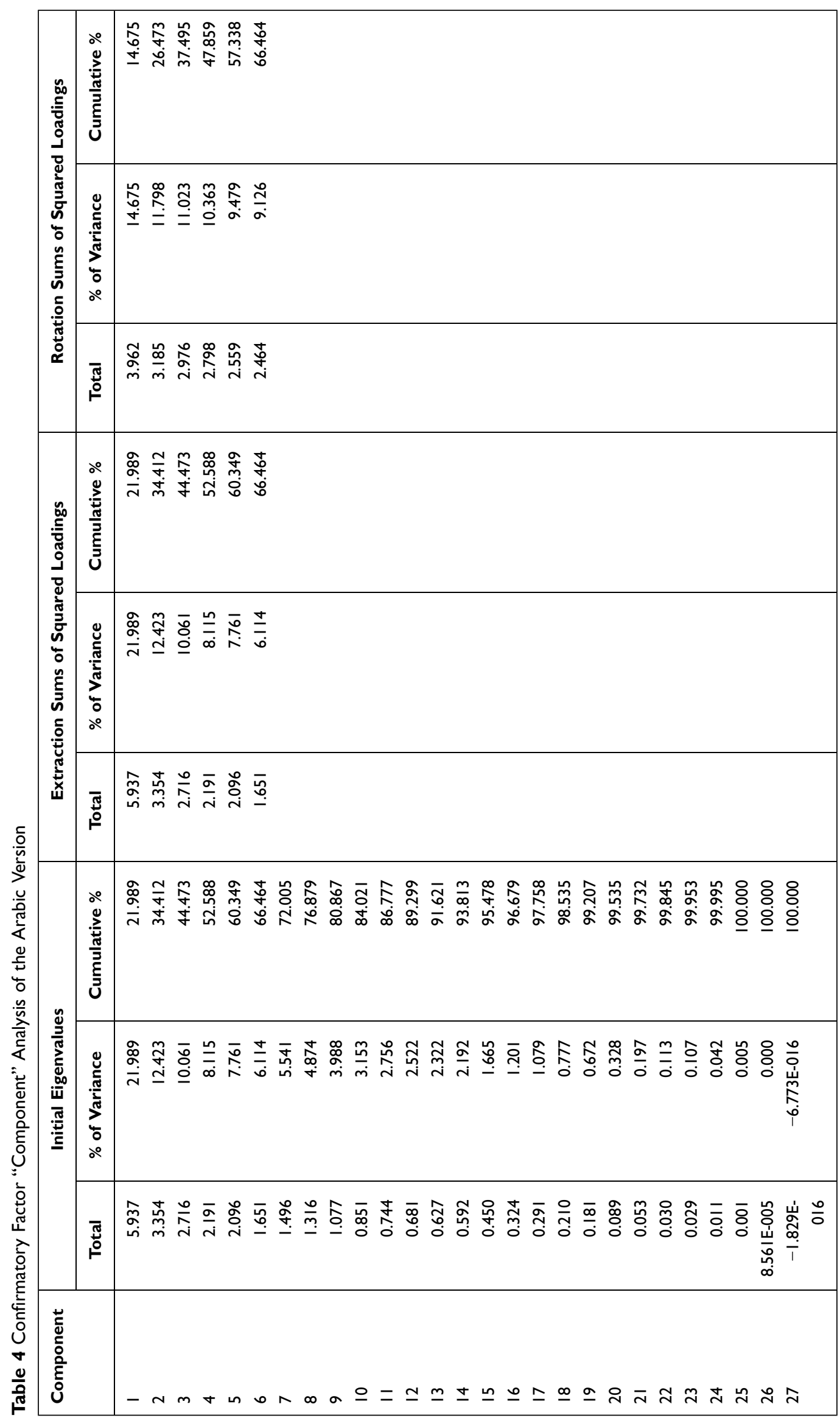


Table 5 Rotated Component Matrix

\begin{tabular}{|c|c|c|c|c|c|c|}
\hline \multirow[t]{2}{*}{ Scale Items } & \multicolumn{6}{|c|}{ Component } \\
\hline & $\begin{array}{l}\text { Anxiety or } \\
\text { Fear of Being } \\
\text { Affected }\end{array}$ & $\begin{array}{l}\text { Practices to Avoid } \\
\text { Infection with } \\
\text { COVID-19 }\end{array}$ & $\begin{array}{l}\text { Attitudes About } \\
\text { the Affected } \\
\text { Individuals }\end{array}$ & $\begin{array}{l}\text { Being Avoided } \\
\text { or Judged by } \\
\text { Others }\end{array}$ & $\begin{array}{l}\text { Policy of } \\
\text { Health } \\
\text { Settings }\end{array}$ & $\begin{array}{l}\text { Willingness to } \\
\text { Care for COVID-19 } \\
\text { Patients }\end{array}$ \\
\hline Item I & 0.656 & & & & & 0.516 \\
\hline Item 2 & 0.745 & & & & & \\
\hline Item 3 & 0.523 & & & & 0.579 & \\
\hline Item 4 & & & & & 0.673 & \\
\hline Item 5 & $0.81 \mathrm{I}$ & & & & & \\
\hline Item 6 & 0.823 & & & & & \\
\hline Item 7 & 0.478 & & & & & \\
\hline Item 8 & & 0.610 & & & & \\
\hline Item 9 & & 0.599 & & & 0.434 & \\
\hline Item 10 & & & & & 0.646 & \\
\hline Item II & & & & & & -0.518 \\
\hline Item 12 & & & & & $-0.748-$ & \\
\hline Item 13 & & & & 0.864 & & \\
\hline Item 14 & & & & 0.769 & 0.404 & \\
\hline Item 15 & 0.473 & & 0.415 & 0.448 & & \\
\hline Item 16 & & & 0.684 & & & \\
\hline Item 17 & & & 0.769 & & & \\
\hline Item 18 & & & 0.825 & & & \\
\hline Item 19 & & & & & & 0.547 \\
\hline Item 20 & & & & & & -0.752 \\
\hline Item 21 & & 0.834 & & & & \\
\hline Item 22 & & 0.729 & & & & \\
\hline Item 23 & & 0.746 & & & & \\
\hline Item 24 & & & 0.408 & & & \\
\hline Item 25 & & 0.453 & & & & $0.40 \mathrm{I}$ \\
\hline Item 26 & & & & $-0.555-$ & & \\
\hline Item 27 & & & 0.454 & & & 0.630 \\
\hline
\end{tabular}

Response Team must put in place a robust psychosocial intervention plan for stigmatized persons to help them cope with the stigma and help in its prevention. ${ }^{29}$

Finally and most importantly, providing healthcare workers with emotional support increases productivity and decreases staff turnover. The WHO supports this recommendation with a report in 2019 , which indicates that workplace stigmatization as well as harassment can have a substantial adverse impact on physical and mental health, which may be reflected in increased staff turnover and reduced productivity. ${ }^{25}$ Moreover, studies focused on organizational-level interventions to promote mental health in the workplace proved positive mental health and well-being among healthcare workers. One study in particular by Gray et al highlighted a strong rationale for improving mental health in the workplace from constant evaluation and improvement on the organizational level; based on their systematic review results, an effective approach to healthcare workers' mental health is an organizational-level intervention. Still, with all the research on eliminating stigma and the approaches to healthcare workers' mental health and well-being, more research needs to include low-income countries and especially those facing an unprecedented economic crisis. ${ }^{26}$

\section{Limitations and Recommendations}

This research has some limitations. The main one is that the sample is a snowball sample. In online surveys, selection bias occurs inevitably. The pilot study for the Arabic language version only included $(n=27)$ participants from Iraq and the English language version of the scale included $(n=33)$ from Jordan. Therefore, the researchers should not assume that the study sample is representative of the health care providers due to the small number used for the 
purpose of validating the scale. The questionnaire was translated from English to Arabic, and the researchers cannot infer that the conclusions apply to other languages. The inclusion in the study sample of people from Iraq and Jordan only could introduce some bias and limit the generalizability; a multi-country study is suggested to further validated in other countries. As personal data were not collected, it was impossible to know whether the same person or the same IP address could send more than one questionnaire.

\section{Conclusion}

The findings of this study showed a satisfactory internal consistency of both Arabic and English versions of the scale following pre-test and post-test correlations. The tool has evident strength and robust results in all the validation measures. Institutionalizing and embedding the stigma assessment and management in routine clinical practice is very important and could create a healthy work environment for healthcare providers and implement effective strategies to fight COVID-19 and its related collateral damage.

\section{Acknowledgments}

The publication of this article was funded by the Qatar National Library.

\section{Disclosure}

The authors report no conflicts of interest in this work.

\section{References}

1. Haleem A, Javaid M, Vaishya R. Effects of COVID 19 pandemic in daily life. Current Med Res Pract. 2020;10:78-79. doi:10.1016/j. cmrp.2020.03.011

2. Mohammed IA, Ali AH, Al Shenaty JN. Clinical course and disease outcomes in hospitalized patients with 2019 novel Corona virus disease at Ibn-Al Khateeb Hospital in Baghdad, Iraq. J Fac Med Baghdad. 2020;62(3). doi:10.32007/jfacmedbagdad.6231775

3. World Health Organization. Coronavirus disease ( COVID-19): weekly epidemiological update; 2020.

4. Nashwan AJ, Abujaber AA, Mohamed AS, Villar RC, Al-Jabry MM. Nurses' willingness to work with COVID-19 patients: The role of knowledge and attitude. Nurs Open. 2020;8:695-701.

5. McKay D, Heisler M, Mishori R, Catton H, Kloiber O. Attacks against health-care personnel must stop, especially as the world fights COVID-19. Lancet. 2020;395(10239):1743-1745. doi:10.1016/ S0140-6736(20)31191-0

6. Mohammed QQ. Perceived stigma and treatment-seeking behavior in individuals with substance use disorder in Baghdad. J Contemp Med Sci. 2016;2(8):153-157. doi:10.22317/jcms.2016130

7. Bagcchi S. Stigma during the COVID-19 pandemic. Lancet Infect Dis. 2020;20(7):782. doi:10.1016/S1473-3099(20)30498-9
8. Earnshaw VA, Quinn DM. The impact of stigma in healthcare on people living with chronic illnesses. J Health Psychol. 2012;17 (2):157-168. doi:10.1177/1359105311414952

9. Prasad SK, Karahda A, Singh P, Gupta R. Role of mental health professionals in dealing with the stigma attached to COVID-19. General Psychiatry. 2020;33(5):e100298. doi:10.1136/gpsych-2020100298

10. World Health Organization. Social Stigma associated with COVID-19; 2020. Available from: https://www.who.int/docs/defaultsource/coronaviruse/covid19-stigma-guide.pdf. Accessed October 13, 2020.

11. Singh R, Subedi M. COVID-19 and Stigma: social discrimination towards frontline healthcare providers and COVID-19 recovered patients in Nepal. Asian J Psychiatr. 2020;53:102222. doi:10.1016/ j.ajp.2020.102222

12. Villa S, Jaramillo E, Mangioni D, Bandera A, Gori A, Raviglione MC. Stigma at the time of the COVID-19 pandemic. Clin Microbiol Infect. 2020;26(11):1450-1452. doi:10.1016/j. cmi.2020.08.001

13. McCoach DB, Gable RK, Madura JP. Review of the steps for designing an instrument. In: Instrument Development in the Affective Domain. Springer; 2013:277-284.

14. World Health Organization. Process of translation and adaptation of instruments; 2009. Available from: http://www.who.int/substance abuse/research_tools/translation/en/. Accessed October 29, 2021.

15. Alavi K, Isa $\bar{K}$, Palpanadan ST. Application of rasch model on resilience in higher education: an examination of validity and reliability of Malaysian Academician Happiness Index (MAHI). Int J Higher Edu. 2020;9(4):261-271. doi:10.5430/ijhe.v9n4p261

16. Taherdoost H. Validity and reliability of the research instrument; how to test the validation of a questionnaire/survey in a research. SSRN Electronic J. 2016. doi:10.2139/ssrn.3205040

17. Hinton PR. Statistics Explained. Routledge; 2014.

18. Anastasi A, Urbina S. Psychological Testing. Prentice Hall/Pearson Education; 1997

19. Jain M, Sinha R, Kar SK, Yadav M. A questionnaire survey of stigma related to human immunodeficiency virus infection/acquired immunodeficiency syndrome among healthy population. Community Acquired Infect. 2017;4(1):6.

20. Mucci N, Giorgi G, Roncaioli M, Perez JF, Arcangeli G. The correlation between stress and economic crisis: a systematic review. Neuropsychiatr Dis Treat. 2016;12:983. doi:10.2147/NDT.S98525

21. Van Rie A, Sengupta S, Pungrassami P, et al. Measuring stigma associated with tuberculosis and HIV/AIDS in southern Thailand: exploratory and confirmatory factor analyses of two new scales. Trop Med Int Health. 2008;13(1):21-30. doi:10.1111/j.13653156.2007.01971.x

22. Drewes J, Kleiber D. Contagiousness under antiretroviral therapy and stigmatization toward people with HIV. AIDS Care. 2014;26 (11):1383-1386. doi:10.1080/09540121.2014.913768

23. Abdelhafiz AS, Alorabi M. Social stigma: the hidden threat of COVID-19. Front Public Health. 2020;8. doi:10.3389/ fpubh.2020.00429

24. Tomlin J, Dalgleish-Warburton B, Lamph G. Psychosocial support for healthcare workers during the COVID-19 pandemic. Front Psychol. 2020;11:1960. doi:10.3389/fpsyg.2020.01960

25. World Health Organization. Mental health in the workplace; 2019. Available from: https://www.who.int/teams/mental-health-andsubstance-use/mental-health-in-the-workplace. Accessed November 16, 2020.

26. Gray P, Senabe S, Naicker N, Kgalamono S, Yassi A, Spiegel JM. Workplace-based organizational interventions promoting mental health and happiness among healthcare workers: a realist review. Int J Environ Res Public Health. 2019;16(22):4396. doi:10.3390/ ijerph16224396 
27. Ruiz NG, Horowitz JM, Tamir C. Many Black and Asian Americans say they have experienced discrimination amid the COVID-19 outbreak. Pew Research Center. 2020;1:45.

28. Mostafa A, Sabry W, Mostafa NS. COVID-19-related stigmatization among a sample of Egyptian healthcare workers. PLoS One. 2020;15 (12):e0244172. doi:10.1371/journal.pone.0244172
29. Adom D, Mensah JA, Osei M. The psychological distress and mental health disorders from COVID-19 stigmatization in Ghana. Soc Sci Humanities Open. 2021;4:100186. doi:10.1016/j.ssaho.2021.100186

\section{Publish your work in this journal}

The Journal of Multidisciplinary Healthcare is an international, peerreviewed open-access journal that aims to represent and publish research in healthcare areas delivered by practitioners of different disciplines. This includes studies and reviews conducted by multidisciplinary teams as well as research which evaluates the results or conduct of such teams or healthcare processes in general. The journal covers a very wide range of areas and welcomes submissions from practitioners at all levels, from all over the world. The manuscript management system is completely online and includes a very quick and fair peer-review system. Visit http://www.dovepress.com/testimonials. php to read real quotes from published authors. 